\title{
Biological Impact of Pd (II) Complexes: Synthesis, Spectral Characterization, In Vitro Anticancer, CT-DNA Binding, and Antioxidant Activities
}

\author{
Nitin Kumar Sharma, Rakesh Kumar Ameta, and Man Singh \\ School of Chemical Sciences, Central University of Gujarat, Gandhinagar 382030, India \\ Correspondence should be addressed to Man Singh; mansingh50@hotmail.com
}

Received 12 October 2015; Revised 22 December 2015; Accepted 20 January 2016

Academic Editor: Arie Zask

Copyright (C) 2016 Nitin Kumar Sharma et al. This is an open access article distributed under the Creative Commons Attribution License, which permits unrestricted use, distribution, and reproduction in any medium, provided the original work is properly cited.

\begin{abstract}
A new series of Pd (II) complexes of methyl substituted benzylamine ligands (BLs) has been synthesized and characterized via spectroscopic techniques such as UV/Vis. FTIR, LCMS, ${ }^{1} \mathrm{H}$, and ${ }^{13} \mathrm{C}$ NMR. The UV/Vis study in DMSO, DMSO + water, and DMSO + PBS buffer $(\mathrm{pH}=7.2)$ confirmed their molecular sustainability in liquids. Their in vitro anticancer activity against breast cancer cell lines such as MCF-7 and MDA-MB-231 makes them interesting for in vivo analysis. Their stronger DNA binding activity (DBA) compared with free ligand suggested them as a good DNA binder. DBA was further confirmed by physicochemical studies such as surface tension and viscosity of complex + DNA which inferred the disruption of DNA and intercalation of complexes, respectively. Their \% binding activity, \% disruption of DNA base pairs (DNABP), and \% intercalating strength are reported in this paper for the first time for better understanding of DNA binding mechanism. Along with this, their scavenging activity (SA) determined through DPPH free radical and the results indicate good antioxidant behaviour of complexes.
\end{abstract}

\section{Introduction}

From the last few decades, the transition metal complexes with different amine ligands have drawn a significant interest in exploring anticancer activities, specifically related to solid tumor chemotherapies [1-4]. The breast cancer, a solid tumor, is one of the major issues in health care in terms of morbidity, mortality, and therapy costs [5]. To overcome these problems many more drugs have been introduced into the market but their response to therapy is still very poor. However, such drugs have not been found to be much effective for treatment of solid tumors due to their pertinent side effects such as nephrotoxicity, drug resistance, and renal and cervical problems [6,7]. Therefore, the foremost target of most research groups is to find a convenient anticancer drug that can be used efficiently for the treatment of solid tumors. Recently, many Pd (II) complexes with promising anticancer activity against tumor cell lines have been synthesized and reported elsewhere [8]. In such studies, a good correlation was observed between the cytostatic activity and lipophilicity of the Pd complexes [6-8]. In fact, the Pd complexes, as a nonplatinum complex, have recently been reviewed to have a significant antitumor activity and lower side effects compared to cisplatin [5]. As an essential feature of metal-containing anticancer agents, Pd complexes are expected to have less kidney toxicity than cisplatin $[7,8]$. Further many new Pd complexes with amine ligands having promising anticancer activities with lower side effect have recently been reported [5-12]. Bearing in mind that Pd (II) complexes are about 105 times more reactive than their Pt (II) analogues, the lower antitumor activity of Pd compounds has been attributed to very rapid hydrolysis of the leaving groups that dissociate readily in solution, leading to reactive species far from their pharmacological targets $[9,10]$.

Keeping above inconveniences, a new series of Pd (II) complexes has been synthesized with methyl substituted BLs and analyzed their in vitro antitumor activity on breast cancer cell lines MCF-7 and MDA-MB-231 which expressed effective anticancer potential. Since DNA is a primary molecular target of anticancer drugs and ascertains an extent of 
drug's chemotherapeutic potential, the DBA of synthesized complexes have chosen to investigate their anticancer nature $[8,13]$. For better understanding of DBA, we have also calculated the \% binding activity, \% disruption of DNABP, and \% intercalating strength of complexes by using newly developed quantitative equation. Apart from DNA binding, the antioxidant activity has also proven the anticancer nature and medicinal significance of the Pd (II) complexes which have been the criteria for studying their antioxidant activity [14-16]. Therefore, our study of Pd (II) complexes leads to a better understanding of their biological and medicinal applications.

\section{Experimental Section}

2.1. Materials and Methods. Palladium dichloride $\left(\mathrm{PdCl}_{2}\right)$, benzylamine ligands (BLs), CT-DNA, Tris buffer, DMSO, and ethanol $(>99.5 \%)$ were procured from Sigma-Aldrich and used as received. Elemental analysis was made with a Euro vector $\mathrm{CHN}$ analyzer and UV/Vis spectra were recorded with a Spectro 2060 plus spectrophotometer over 200-600 nm by using $1 \mathrm{~cm}$ path length cuvette. FTIR (Perkin Elmer) spectra were taken with $\mathrm{KBr}$ palate where polystyrene thin film was used as a calibration standard. ${ }^{1} \mathrm{H}$ and ${ }^{13} \mathrm{C}$ NMR spectra were recorded in DMSO- $d_{6}(\mathrm{NMR}, 99.99 \%)$ with a Bruker-Biospin Avance-III $500 \mathrm{MHz}$ FT-NMR spectrometer. Mass spectra were obtained with PE SCIEX API 165 with +ve ESI mode with ammonium acetate and acetonitrile in $1: 9 \mathrm{v} / \mathrm{v}$ ratio as mobile phase. Their molecular sustainability was determined in DMSO, DMSO/water, and DMSO/phosphate buffer of $\mathrm{pH}=7.2$. Buffer solution was prepared by adding $70 \mathrm{~mL} 0.1 \mathrm{M}$ aqueous $\mathrm{NaOH}$ into $0.1 \mathrm{M}$ aqueous $\mathrm{KH}_{2} \mathrm{PO}_{4}$ solution. The $\mathrm{pH}$ of a resultant buffer was checked with RS-232 modelled Cyber scan pH 2100, EUTECH pH meter.

2.2. General Consideration for Synthesis. Initially, $\mathrm{PdCl}_{2}$ and BLs were separately dissolved in freshly prepared aqueous ethanol (absolute ethanol and Milli-Q water in 1:1.5) in $1: 2$ molar ratio, using $1 \mathrm{MLH}$ magnetic stirrer. The BLs solutions were added dropwise in metal compound solution with continuous stirring at room temperature. After $16 \mathrm{~h}$, the mixture turned from light brown to greenish for Pd complexes and precipitates were formed. The ppts were filtered off and washed several times with chilled water/ethanol in 1:1 ratio and kept overnight in vacuum oven at room temperature for absolute dryness.

\subsection{Characterization Data}

2.3.1. Complex 1: $\mathrm{C}_{16} \mathrm{H}_{20} \mathrm{~N}_{2} \mathrm{Pd}$ [Pd2MBA]. Yield: $0.1810 \mathrm{~g}$, $74.76 \%$. Elemental analysis, found: $C, 55.74 ; \mathrm{H}, 5.26 ; \mathrm{N}$, 8.13\%. Calcd for $\mathrm{C}_{16} \mathrm{H}_{20} \mathrm{~N}_{2} \mathrm{Pd}$ : C, 55.82; H, 5.44; N, 8.22\%. IR (KBr): $v_{\max } / \mathrm{cm}^{-1} 3300$ and $3214.2\left(\mathrm{NH}_{2}\right), 1493$ and 1449.7 ( $\mathrm{Ph}, \mathrm{C}=\mathrm{C}$ ), 740.7 (mono substituted $\mathrm{Ph}$ ), 1051.9 (C$\mathrm{N}), 479.6(\mathrm{Pd}-\mathrm{N}) .{ }^{1} \mathrm{H}$ NMR $\left(125 \mathrm{MHz} ; \mathrm{DMSO}-d_{6} ; \mathrm{Me}_{4} \mathrm{Si}\right)$ $\delta 2.09\left(2 \mathrm{H}, \mathrm{s}, \mathrm{PhCH}_{2} \mathrm{NH}_{2}\right), 3.93\left(2 \mathrm{H}, \mathrm{s}, \mathrm{PhCH}_{2} \mathrm{NH}_{2}\right), 2.50$ (3H. s, $\left.\mathrm{PhCH}_{3}\right), 7.37-7.43(1 \mathrm{H}, \mathrm{d}, \mathrm{PhH}, J=13.9 \mathrm{~Hz}), 7.45-$ $7.47(1 \mathrm{H}, \mathrm{d}, \mathrm{PhH}, J=7.3 \mathrm{~Hz})$ and $7.35-7.38(1 \mathrm{H}, \mathrm{m}, \mathrm{PhH})$. ${ }^{13} \mathrm{C}$ NMR (125 MHz; DMSO- $\left.d_{6} ; \mathrm{Me}_{4} \mathrm{Si}\right) \delta 47.67$ (C1), 136.52
(C2), 145.72 (C3), 129.99 (C4), 128.83 (C5), 125.89 (C6), 127.40 (C7) and 18.75 (C8). +ve ESI-MS: $m / z$ 346.9 $[\mathrm{M}+1]$ (calc. for $\left.\left[\mathrm{C}_{16} \mathrm{H}_{20} \mathrm{~N}_{2} \mathrm{Pd}\right]=374.7\right)$. UV/Vis in DMSO: $\lambda_{\max }[\varepsilon$ $\left.\left(\mathrm{dm}^{3} \mathrm{~mol}^{-1} \mathrm{~cm}^{-1}\right)\right]=275$ (2569), $330(664), 370(477) \mathrm{nm}$, in DMSO: water (1:1): $\lambda_{\max }\left[\varepsilon\left(\mathrm{dm}^{3} \mathrm{~mol}^{-1} \mathrm{~cm}^{-1}\right)\right]=270(2921)$, 340 (358) nm, in DMSO: phosphate buffer (1:1): $\lambda_{\max }[\varepsilon$ $\left.\left(\mathrm{dm}^{3} \mathrm{~mol}^{-1} \mathrm{~cm}^{-1}\right)\right]=265(2252), 340(410) \mathrm{nm}$.

2.3.2. Complex 2: $\mathrm{C}_{16} \mathrm{H}_{20} \mathrm{~N}_{2} \mathrm{Pd}$ [Pd3MBA]. Yield: $0.1722 \mathrm{~g}$, $63.26 \%$. Elemental analysis, found: C, 55.74; $\mathrm{H}, 5.26 ; \mathrm{N}$, 8.13\%. Calcd for $\mathrm{C}_{16} \mathrm{H}_{20} \mathrm{~N}_{2} \mathrm{Pd}$ : C, 55.79; H, 5.33; N, 8.19\%. IR (KBr): $v_{\max } / \mathrm{cm}^{-1} 3293$ and $3210\left(\mathrm{NH}_{2}\right), 1493$ and 1449.7 (Ph, C=C), 744.64 (mono substituted Ph), $1099(\mathrm{C}-\mathrm{N}), 437.42$ $(\mathrm{Pd}-\mathrm{N}) .{ }^{1} \mathrm{H}$ NMR $\left(500 \mathrm{MHz} ; \mathrm{DMSO}-d_{6} ; \mathrm{Me}_{4} \mathrm{Si}\right) \delta 2.086(2 \mathrm{H}$, s, $\left.\mathrm{PhCH}_{2} \mathrm{NH}_{2}\right), 3.932\left(2 \mathrm{H}, \mathrm{s}, \mathrm{PhCH}_{2} \mathrm{NH}_{2}\right), 2.404(3 \mathrm{H}, \mathrm{s}$, $\left.\mathrm{PhCH}_{3}\right), 7.21-7.23(1 \mathrm{H}, \mathrm{d}, \mathrm{PhH}, J=7.2 \mathrm{~Hz}), 7.08-7.10(1 \mathrm{H}$, $\mathrm{d}, \mathrm{PhH}, J=7.2)$ and $7.12-7.20(1 \mathrm{H}, \mathrm{s}, \mathrm{PhH}) .{ }^{13} \mathrm{C} \mathrm{NMR}$ $\left(125 \mathrm{MHz} ; \mathrm{DMSO}-d_{6} ; \mathrm{Me}_{4} \mathrm{Si}\right) \delta 47.674(\mathrm{C} 1), 138.36$ (C2), 137.23 (C3), 129.04 (C4), 127.90 (C5), 125.48 (C6), 128.15 (C7) and 20.98 (C8). +ve ESI-MS: $m / z 346.05[\mathrm{M}+1]$ (calc. for $\left.\left[\mathrm{C}_{16} \mathrm{H}_{20} \mathrm{~N}_{2} \mathrm{Pd}\right]=344.75\right)$. UV/Vis in DMSO: $\lambda_{\max }[\varepsilon$ $\left.\left(\mathrm{dm}^{3} \mathrm{~mol}^{-1} \mathrm{~cm}^{-1}\right)\right]=275$ (2509), $340(595), 370(486) \mathrm{nm}$, in DMSO: water $(1: 1): \lambda_{\max }\left[\varepsilon\left(\mathrm{dm}^{3} \mathrm{~mol}^{-1} \mathrm{~cm}^{-1}\right)\right]=270(2745)$, $340(344) \mathrm{nm}$, in DMSO: phosphate buffer (1:1): $\lambda_{\max }[\varepsilon$ $\left.\left(\mathrm{dm}^{3} \mathrm{~mol}^{-1} \mathrm{~cm}^{-1}\right)\right]=265(2086), 340(412) \mathrm{nm}$.

2.3.3. Complex 3: $\mathrm{C}_{16} \mathrm{H}_{20} \mathrm{~N}_{2} \mathrm{Pd}$ [Pd4MBA]. Yield: $0.1785 \mathrm{~g}$, 74.20\%. Elemental analysis, found: C, 55.74; H, 5.26; N, 8.13\%. Calcd for $\mathrm{C}_{16} \mathrm{H}_{20} \mathrm{~N}_{2}$ Pd: C, 55.88; H, 5.29; N, 8.21\%. IR (KBr): $v_{\max } / \mathrm{cm}^{-1} 3257$ and $3210\left(\mathrm{NH}_{2}\right), 1453$ and $1355(\mathrm{Ph}, \mathrm{C}=\mathrm{C})$, 756.46 (mono substituted $\mathrm{Ph}$ ), 1000.7 and $1036.1(\mathrm{C}-\mathrm{N}), 492.6$ $(\mathrm{Pd}-\mathrm{N}) .{ }^{1} \mathrm{H} \mathrm{NMR}\left(500 \mathrm{MHz} ; \mathrm{DMSO}-d_{6} ; \mathrm{Me}_{4} \mathrm{Si}\right) \delta 2.09(2 \mathrm{H}, \mathrm{s}$, $\mathrm{PhCH}_{2} \mathrm{NH}_{2}$ ), $3.93\left(2 \mathrm{H}, \mathrm{s}, \mathrm{PhCH}_{2} \mathrm{NH}_{2}\right), 2.31\left(3 \mathrm{H}, \mathrm{s}, \mathrm{PhCH}_{3}\right)$, 7.33-7.35 (1H, d, PhH, J = 6.0 Hz), 7.18-7.20 (1H, d, PhH, $J=10.72 \mathrm{~Hz})$ and $7.25(1 \mathrm{H}, \mathrm{s}, \mathrm{PhH}) .{ }^{13} \mathrm{C} \mathrm{NMR}(125 \mathrm{MHz}$; DMSO- $d_{6}$; $\left.\mathrm{Me}_{4} \mathrm{Si}\right) \delta 47.67$ (C1), 139.11 (C2), 127.89 (C3), 128.76 (C4), 138.23 (C5), 129.11 (C6), 128.14 (C7) and 20.29 (C8). +ve ESI-MS: $m / z 346.9[\mathrm{M}+1]$ (calc. for $\left[\mathrm{C}_{16} \mathrm{H}_{20} \mathrm{~N}_{2} \mathrm{Pd}\right]=$ 344.75). UV/Vis in DMSO: $\lambda_{\max }\left[\varepsilon\left(\mathrm{dm}^{3} \mathrm{~mol}^{-1} \mathrm{~cm}^{-1}\right)\right]=280$ (2208), 340 (447), 370 (368) nm, in DMSO: water (1:1): $\lambda_{\max }\left[\varepsilon\left(\mathrm{dm}^{3} \mathrm{~mol}^{-1} \mathrm{~cm}^{-1}\right)\right]=265(2770), 340(286) \mathrm{nm}$, in DMSO: phosphate buffer $(1: 1): \lambda_{\max }\left[\varepsilon\left(\mathrm{dm}^{3} \mathrm{~mol}^{-1} \mathrm{~cm}^{-1}\right)\right]=$ 265 (2276), 340 (371) nm.

\section{Biological Evaluation}

3.1. In Vitro Anticancer Activity. Cell viability was estimated colorimetrically using 2-(3-diethylamino-6 diethylazaniumylidene-xanthen-9-yl)-5-sulfobenzenesulfonate, SRB (sulforhodamine B) as standard assay with high reproducibility [17].

3.1.1. Cell Lines and Culture Conditions. Human breast cancer cell lines MCF-7 and MDA-MB-231 were obtained from NCI, USA, and grown in minimal essential medium (MEM). Eagles media were supplemented with $10 \%$ heat inactivated fetal bovine serum (FBS, Sigma-Aldrich), 2 mM L-glutamine, and $1 \mathrm{~mm}$ sodium pyruvate (Hyclone) in humidified $\mathrm{CO}_{2}$ incubator. 
3.1.2. Assay of Cytotoxicity in Cancer Cell Lines. Cytotoxicity of Pd (II) complexes was determined by SRB assay where E5000 cells were seeded into each well of a 96-well clear flat bottom polystyrene tissue culture plate and incubated for $2 \mathrm{~h}$ in MEM. An additional $190 \mathrm{~mL}$ cell suspension was added in each well containing $10 \mathrm{~mL}$ test sample in $10 \%$ DMSO with $10 \mathrm{~mL}$ Adriamycin (doxorubicin) as a positive drug control. Each experiment was carried out in 3 replicate wells. After an incubation of $48 \mathrm{~h}, 100 \mathrm{~mL}$ of $0.057 \%$ SRB solution (w/v) was added in each well. Then $200 \mathrm{~mL}$ of $10 \mathrm{mM}$ Tris base solution $(\mathrm{pH}=10.5)$ was added into each well and shaken smoothly. The cell viability was assayed by absorption at $510 \mathrm{~nm}$ with a microplate reader. The experiments were repeated thrice with 3 replicates each time and 99\% reproducibility was obtained.

3.2. DNA Binding. CT-DNA (analytical grade, SigmaAldrich) was used as received. Tris- $\mathrm{HCl}$ buffer $(10 \mathrm{mM}, \mathrm{pH}$ = 7.2) was prepared in Milli-Q water for $50 \mu \mathrm{M}$ DNA stock solution and used for absorption titration, viscosity, surface tension, conductivity, and zeta potential measurements.

3.2.1. Absorption Spectroscopy. DNA concentration was determined using an absorption spectrophotometer that gave $6600 \mathrm{M}^{-1} \mathrm{~cm}^{-1}$, a molar absorption coefficient at $260 \mathrm{~nm}[18,19]$. The CT-DNA in buffer gave a ratio of UV absorbance at 260 and $280 \mathrm{~nm}$ which is found to be 1.8 to 1.9 and indicates a presence of protein free DNA [20-22]. The $10,30,50,70$, and $90 \mu \mathrm{M}$ complex solutions were prepared in $10 \%$ DMSO in Tris buffer for Pd(BLs) $)_{2}$ to which the DNA stock solutions were added. Their $\mathrm{ri}=[$ complex $] /[\mathrm{DNA}]$ at $0.2,0.6,1,1.4$, and 1.8 were calculated by absorption titration. Before recording UV spectra the $\mathrm{Pd}(\mathrm{BLs})_{2}+\mathrm{DNA}$ solutions were incubated for $15 \mathrm{~min}$ at $\mathrm{rt}$ to enable sufficient and reproducible DNA binding with complexes. Further their binding strength, an intrinsic binding constant $\left(K_{b}\right)$ with CT-DNA, was obtained by monitoring a change in DNA absorbance on increasing Pd(BLs) ${ }_{2}$ concentrations and calculated with the following equation [23]:

$$
\frac{[\mathrm{DNA}]}{\varepsilon_{a}-\varepsilon_{b}}=\frac{[\mathrm{DNA}]}{\varepsilon_{b}-\varepsilon_{f}}+\frac{1}{K_{b}\left(\varepsilon_{b}-\varepsilon_{f}\right)} .
$$

$\varepsilon_{a}, \varepsilon_{f}$, and $\varepsilon_{b}$ are apparent, free, and bound complex extinction coefficients, respectively. $\varepsilon_{f}$ was determined from a calibration curve of an isolated metal complex, with BeerLambert law. $\varepsilon_{a}$ was determined as a ratio of the measured absorbance and $\mathrm{Pd}$ (II) complexes concentration similar to $A_{\text {obs }} /[\mathrm{Pt}]$. A plot of $[\mathrm{DNA}] /\left(\varepsilon_{a}-\varepsilon_{f}\right)$ versus [complex] produced a slope of $1 /\left(\varepsilon_{b}-\varepsilon_{f}\right)$ and a $Y$ intercept equal to $1 / K_{b}\left(\varepsilon_{b}-\varepsilon_{f}\right) ; K_{b}$ is the ratio of slope to the $Y$ intercept [23].

\subsubsection{Physicochemical Analysis}

(1) Viscosity and Surface Tension. Viscosity and surface tension measurements were made using BMS at $298.15 \mathrm{~K}$ and the temperature controlled through an auto temperature control LAUDA ALPHA RA 8 thermostat [24, 25]. About 15 to 20 measurements were made for each composition, enabling high reproducibility and precision, from which viscous flow time (VFT) and pendent drop numbers (PDN) were calculated. $\left(\eta / \eta^{0}\right)^{1 / 3}$ versus binding ratio was calculated where $\eta$ represents the dynamic viscosity of DNA with complexes while $\eta^{0}$ is the viscosity of a DNA mixture in buffer.

(2) Conductance and Zeta Potential. Conductance and zeta potentials of DNA solutions with and without complexes were measured using LABINDIA, PICO + conductivity and Microtrac Zetatrac, U2771, and DLS, respectively, at $25^{\circ} \mathrm{C}$. Aqueous $\mathrm{KCl}$ at $0.1,0.01$, and $0.001 \mathrm{M}$ of $12.88,1.413$, and $147 \mathrm{mScm}^{-1}$, respectively, were used for calibration of conductivity meter. Similarly, an auto suspended solution of alumina suspension (400-206-100) was used as zeta potential standard. Initially, a set-zero was made with DMSO + Tris buffer for $\mathrm{Pd}(\mathrm{BLs})_{2}$. The DNA concentration for all measurements was kept constant while the concentration of $\mathrm{Pd}(\mathrm{BLs})_{2}$ was varied from 10 to $90 \mu \mathrm{M}$ over $20 \mu \mathrm{M}$ intervals.

3.3. Scavenging Activities. Antioxidant activities have been studied on free radical scavenging of stable 1-2,5-diphenyl-2picrylhydrazyl (DPPH ${ }^{\bullet}$ ) [26]. For this purpose stock solution of complexes and $\mathrm{DPPH}^{\circ}(0.002 \%)$ were mixed in DMSO + water $(1: 1)$ for $\mathrm{Pd}(\mathrm{BLs})_{2}$. For sample preparation, the $\mathrm{DPPH}^{\bullet}$ solution was mixed with a complex solution in $1: 1$ ratio followed by vigorous shaking and thereafter kept in dark for $30 \mathrm{~min}$ incubation. The UV absorbance was measured at $517 \mathrm{~nm}$ with UV/Vis spectrophotometer. Later, the radical scavenging activity was measured and a decrease in DPPH absorbance indicated a radical scavenging activity, calculated with the following equation:

$$
\text { Scavenging activity } \%=\left(\frac{A_{0}-A_{s}}{A_{0}}\right) \times 100 .
$$

The $A_{s}$ is absorbance of $\mathrm{DPPH}^{\bullet}$ with a test compound and $A_{0}$ absorbance of $\mathrm{DPPH}^{\bullet}$ without a test compound. Absorbance data are presented as means $\pm \mathrm{SD}$ of three determinations.

\section{Results and Discussion}

4.1. Synthesis and Characterizations. Initially, the $\mathrm{PdCl}_{2}$ and BLs ligands were mixed in 1:2 molar ratio for the synthesis of $\mathrm{Pd}(\mathrm{BLs})_{2}$ complexes (Figure 1). The reaction was conducted in aqueous ethanol solution for 14 to $16 \mathrm{~h}$ as per reaction scheme given below.

\section{Synthesis of Pd (II) Complexes. Consider}

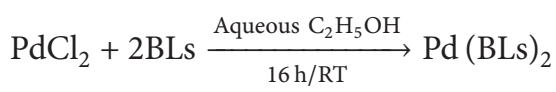

The 3300 to $3119 \mathrm{~cm}^{-1}$ stretching frequencies inferred presence of $-\mathrm{NH}_{2}$ of benzylamine in the $\mathrm{Pd}(\mathrm{BLs})_{2}$ and similarly from 1497 to $1453 \mathrm{~cm}^{-1}$ predicted $\mathrm{C}=\mathrm{C}$ in phenyl ring. The 495.92 to $438.78 \mathrm{~cm}^{-1}$ and $380-348 \mathrm{~cm}^{-1}$ indicates $\mathrm{Pd}-\mathrm{N}$ coordinate and $\mathrm{Pd}-\mathrm{Cl}$ bands, respectively $[26,27]$. In ${ }^{1} \mathrm{H}$ $\mathrm{NMR}$, the $2 \mathrm{H}$ of $-\mathrm{NH}_{2}$ and $\mathrm{PhCH}_{2}$ - appeared at $\delta 3.93$ to 2.09 with singlet for $\mathrm{Pd}(\mathrm{BLs})_{2}$. The $\mathrm{PhCH}_{3}$ proton of benzylamine appeared at $\delta 2.50$ to 2.31 with singlet for all $\mathrm{Pd}(\mathrm{BLs})_{2}$ [28]. 
<smiles>Cc1ccccc1CN</smiles>

2-Methylphenylmethanamine<smiles>Cc1cccc(CN)c1</smiles>

3-Methylphenylmethanamine 4-Methylphenylmethanamine<smiles>Cc1ccc(CN)cc1</smiles>

FIGURE 1: Structures of the ligands $(\mathrm{L}=\mathrm{BLs})$.
Two doublets at $\delta 7.37-7.42$ and 7.49-7.47 having $J=13.9$ and $7.3 \mathrm{MHz}$, respectively, in Pd2MBA for $\mathrm{H}$ of $\mathrm{C} 4$ and $\mathrm{C} 6$ appeared. Similarly, a singlet for $1 \mathrm{H}$ of $\mathrm{C} 3$ at $\delta 7.20$ value and doublets for $1 \mathrm{H}$ of $\mathrm{C} 5$ and $\mathrm{C} 6$ at $\delta 7.08-7.10$ and 7.21$7.23(J=7.2 \mathrm{MHz})$, respectively, were found for Pd3MBA. A doublet at $\delta 7.33-7.35$ and 7.18-7.20 with $J=6.0$ and $10.72 \mathrm{MHz}$, respectively, was confirmed for $1 \mathrm{H}$ of $\mathrm{C} 3$ and $\mathrm{C} 4$ positions while a singlet was confirmed for $1 \mathrm{H}$ of $\mathrm{C} 6$ at $\delta$ 7.25 in Pd4MBA. In ${ }^{13} \mathrm{C}$ NMR, the benzyl carbon $\left(\mathrm{PhCH}_{2}-\right)$ appears at $\delta 47.66$ for all the $\mathrm{Pd}(\mathrm{BLs})_{2}$ [28]. The aromatic ortho, meta, and para $-\mathrm{CH}_{3}$ attached carbon appeared at $\delta 145.72,129.036$, and 138.23, respectively, for the $\mathrm{Pd}(\mathrm{BLs})_{2}$. The carbon of $-\mathrm{CH}_{3}$ at ortho, meta, and para appeared within $\delta 20.98$ to $18.72 \mathrm{ppm}$. The +ve ESI mass spectra of $\mathrm{Pd}(\mathrm{BLs})_{2}$ have found $[\mathrm{M}+1]$ confirming their molecular mass. In UV study, the absorption spectrum consists of a band at $400 \mathrm{~nm}$ and may be assigned as $1 \mathrm{~A}_{1 \mathrm{~g}} \rightarrow 1 \mathrm{~A}_{2 \mathrm{~g}}$ $\left(d_{x y} \rightarrow d_{x^{2}-y^{2}}\right)$ transition occurring with Pd complexes (see ESI, Figures 1-3, in Supplementary Material available online at http://dx.doi.org/10.1155/2016/9245619) [29]. To investigate their molecular stability in solution, the UV/Vis spectral behaviour was investigated in DMSO, DMSO + water, and $\mathrm{DMSO}+$ phosphate buffer for $\mathrm{Pd}(\mathrm{BLs})_{2}$ (ESI, Figures 1-3). The overall patterns of spectra for complexes solution were found to be similar to the different mediums to ensure their stability. Thus our synthesized Pd (II) complexes having $\mathrm{UV} /$ Vis absorption from 265 to $270 \mathrm{~nm}$ and ${ }^{1} \mathrm{H}$ NMR coupling constant between 5 and $10 \mathrm{MHz}$ have confirmed their trans geometry (Figure 2).

4.2. Anticancer Activity. Moving towards the higher anticancer potential of Pd (II) complexes, many of the in vitro studies on different cell lines have been reported, suggesting their cytotoxicity up to some extent [30-33]. In such studies authors have synthesized some Pd complexes with different amine ligands and report their cytotoxicity when tested in vitro [30-33]. It seems that these amine ligands and their derivatives can further improve the cytotoxicities when they reacted with different metals. Therefore, in our study we tried to focus on the factors, namely, nature of ligands and methyl group substitution on ligand, which can modulate the cytotoxicity of such complexes. In this context, we have demonstrated an in vitro anticancer study of some novel Pd complexes using BLs as ligands for better anticancer activity. The complexes were tested in vitro against MCF-7 and MDA-MB-231 human breast tumor cell lines by colorimetric microculture 2-(3-diethylamino-6-diethylazaniumylidenexanthen-9-yl)-5-sulfobenzenesulfonate (SRB) assay and

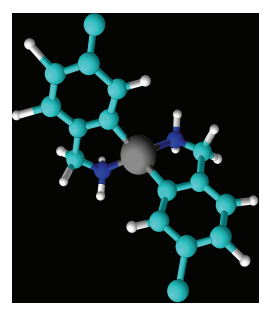

Pd2MBA

FIGURE 2: Structure of synthesized Pd (II) complexes.

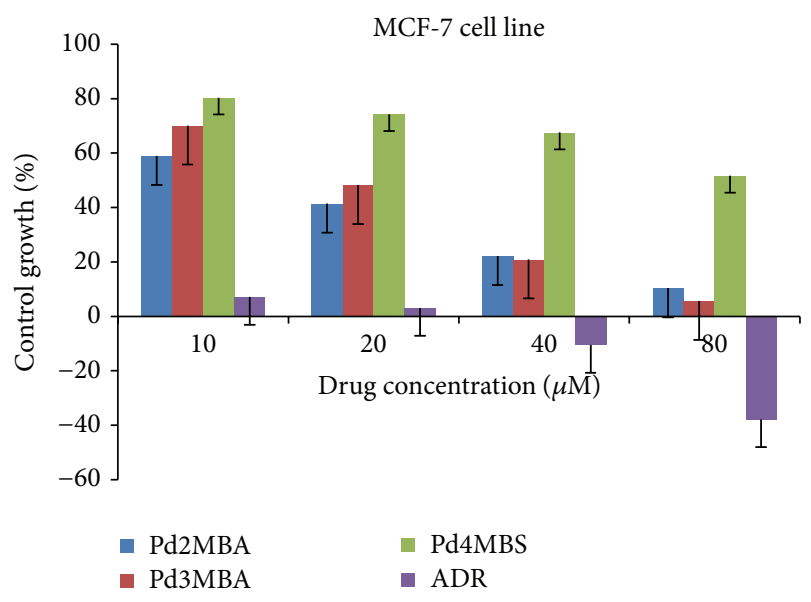

FIGURE 3: Growth curve: human breast cancer cell line (MCF-7).

compared with Adriamycin (ADR) and cisplatin [6, 34]. The MCF-7 and MDA-MB-231 cell lines anticancer activities for $10,20,40$, and $80 \mu \mathrm{M} \mathrm{Pd}(\mathrm{BLs})_{2}$ have been illustrated in Figures 3 and 4 . The analyzed $\mathrm{GI}_{50}$, TGI, and $\mathrm{LC}_{50}$ in $\mu \mathrm{M}$ have inferred $50 \%$ growth inhibition, resultant total growth inhibition, and a net loss of $50 \%$ cells after treatment, respectively (Table 1).

The $\mathrm{GI}_{50}$ value less than $10 \mu \mathrm{M}$ depicts the anticancer activity with respect to $\mathrm{ADR}$ and cisplatin, where the closer $\mathrm{GI}_{50}$ values of Pd2MBA, Pd3MBA, and Pd4MBA from standards make them interesting for testing against other cancerous cell lines.

\subsection{DNA Binding Activity}

4.3.1. Spectrophotometric Method. The DBA explains the anticancer nature of the complex or the drug and can be analyzed by the absorption spectral study. In light of this, 
TABLE 1: $\mathrm{LC}_{50}$, TGI, and $\mathrm{GI}_{50}$ values $(\mu \mathrm{g} / \mathrm{mL})$ against MCF7 and MDA-MB-231 cell lines of complexes, an anticancer analysis.

\begin{tabular}{|c|c|c|c|c|c|c|c|}
\hline \multirow{3}{*}{ Entry } & \multirow{3}{*}{ Complexes } & \multicolumn{6}{|c|}{ Drug concentrations $(\mu \mathrm{M})$ calculated from graph } \\
\hline & & \multicolumn{3}{|c|}{ MCF7 } & \multicolumn{3}{|c|}{ MDA-MB-231 } \\
\hline & & $\mathrm{LC}_{50}$ & TGI & $\mathrm{GI}_{50}$ & $\mathrm{LC}_{50}$ & TGI & $\mathrm{GI}_{50}$ \\
\hline 1 & Pd2MBA & $>80$ & 79.4 & 27.5 & $>80$ & $>80$ & 61.5 \\
\hline 2 & Pd3MBA & $>80$ & 75.6 & 30.1 & $>80$ & $>80$ & 44.6 \\
\hline 3 & Pd4MBA & $>80$ & $>80$ & 78.4 & $>80$ & $>80$ & $>80$ \\
\hline 4 & ADR & 79.2 & 40.5 & $<10$ & 39.85 & $<10$ & $<10$ \\
\hline 5 & Cisplatin & $>30$ & $>30$ & $<10$ & $>30$ & $>30$ & $<10$ \\
\hline
\end{tabular}

the Pd (II) complexes were mixed with CT-DNA at certain concentration and shown the changes in absorbance. Generally, the hypochromism effect in UV study reveals all synthesized complexes intercalative binding strength attributed to an interaction with DNA bases [35, 36]. Similarly, a hyperchromic effect ascribes an external contact or a partial uncoiling of DNA structure; exposing more bases of DNA may be due to electrostatic binding [37, 38]. Such observations have been noticed in the present study where a significant hypochromic effect in absorption titrations of DNA with Pd (II) exposed an intercalation with the base pairs of DNA [37, 38] (ESI, Figures 4-6).
The decrease in UV absorption predicted the strong interactions of $\mathrm{Pd} 2 \mathrm{MBA}, \mathrm{Pd} 3 \mathrm{MBA}$, and Pd4MBA, whose intercalating strengths depend on size and electron densities of interacting aromatic rings with an amine group [35-38]. Their DBA has been found stronger in comparison to a free ligand like benzylamine (ESI, Figure 7).

Comparative \% Binding Affinity of Complexes. For a better understanding of their binding potential, a \% binding affinity (BA) with DNA has been calculated through well known spectrophotometric method at a characteristic wavelength of $260 \mathrm{~nm}$. The \% BA was calculated as per the following equation (Figure 5):

$$
\% \text { BA of Complexes }=\frac{\text { Absorbance of complex at } 260 \mathrm{~nm}-\text { Absorbance of DNA at } 260 \mathrm{~nm}}{\text { Absorbance of DNA at } 260 \mathrm{~nm}} \times 100 \text {. }
$$

Figure 4 shows the BA of each complex where negative sign explains their strong binding with DNA and hypochromism of the complexes.

The all Pd (II) complexes show approximately the same binding activity at each concentration indicating the same binding potential of each complexes. The same binding potential can further be explained by the same geometry of the all complexes. Therefore, it can be understood that the Pd complexes with the same geometry may equally participate when they interacted with DNA.

4.3.2. Physicochemical Method. Along with spectrophotometric study, the physicochemical study, such as viscosity, surface tension, conductivity, and zeta potentials, is also an effective method for better understanding of DBA. Thus, we have mathematically established a comparison of their physicochemical data that presumes their binding affinity with DNA at structural level.

(1) Study of Structural Disruption of CT-DNA. Initially, the complex entertains the DNA and attacks on its base pairs; therefore it weakens the intermolecular forces of bases which results in the disruption of base pairs. Since, it is an intermolecular force disruption and such disruption can be measured by the analysis of surface tension, therefore, we have analysed and compared the surface tensions of
DNA with and without complexes. Generally, the decrease in surface tension infers the force disruption and we have also obtained such results where we compared the surface tension of pure DNA and DNA + complexes. For instance, the surface tension values of the DNA solution with increasing amounts of $\mathrm{Pd}$ (II) complexes $(1 / R=0.2,0.6,1.0,1.4,1.8)$ have decreased as compared to pure DNA (Figure 6).

A decrease in surface tension of Pd (II) complexes + DNA inferred the weakening of intermolecular interaction of DNA bases and has lost interaction with complexes.

Complex Contributions on Disruption of DNA Base Pairs. Surface tension is an important analysing aspect for the disruption of DNA base pairs; therefore, for the advanced study we have also measured and compared the \% disruption of DNA base pairs. The \% complex contribution was calculated on the disruption of DNA (Figure 7):

$$
\begin{aligned}
& \% \text { disruption of DNA base pairs } \\
& =\frac{\gamma \text { of DNA with complexes }-\gamma \text { of pure DNA }}{\gamma \text { of pure DNA }} \\
& \quad \times 100 .
\end{aligned}
$$

Figure 7 shows the disruption of DNABP with respect to complexes and with negative values indicating the weakening 


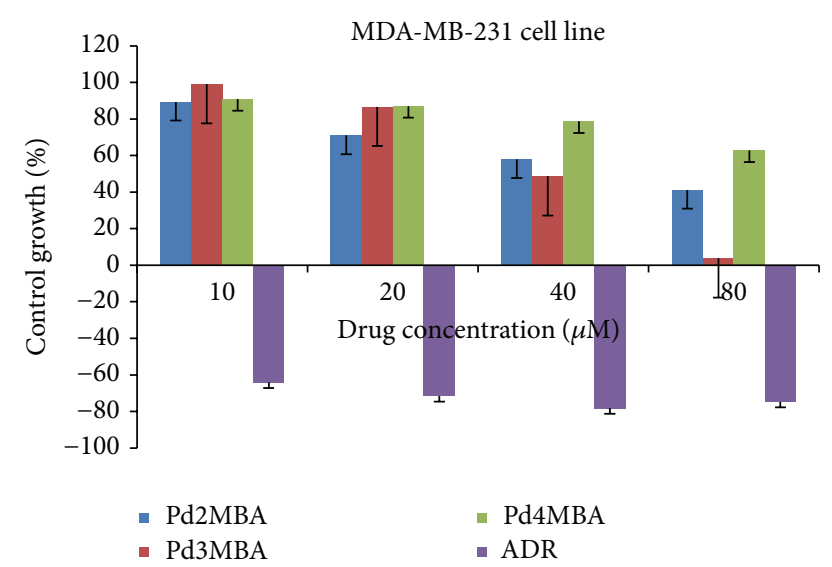

FIGURE 4: Growth curve: human breast cancer cell line (MDA-MB231).

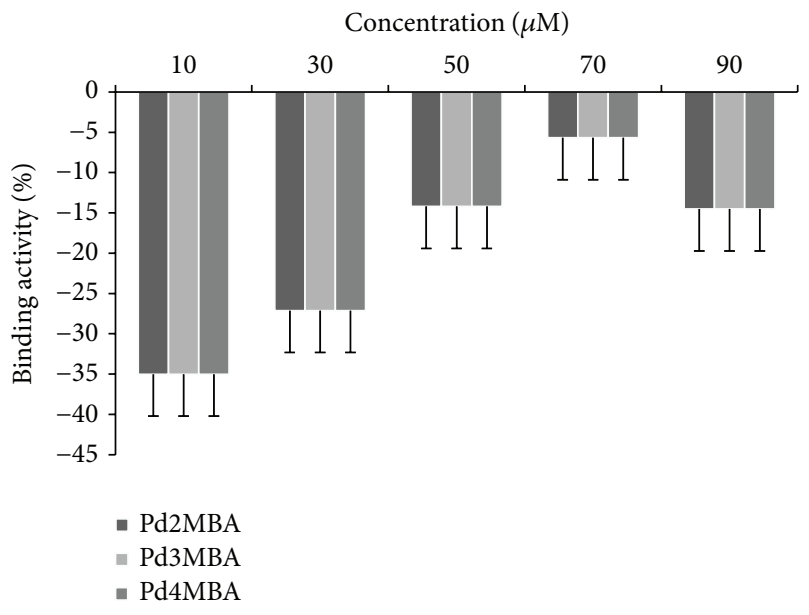

FIGURE 5: \% binding affinity of complexes at $260 \mathrm{~nm}$.

interaction of DNA bases towards disruption. This negative values support the binding affinity (BA) of complexes where the lower $-v e$ values of Pd complexes indicate the disruption of DNABP.

(2) Study on Intercalation Phenomenon of Complexes. For the classical intercalative mode, the viscosity of the DNA solution is increased due to an increase in overall DNA length while it is decreased for a partial nonclassical intercalation process causing a bend or kink in the DNA helix that reduces its effective length concomitantly [39, 40]. For instance, a decrease in relative viscosity with cisplatin is explained due to covalent binding and shortening in an axial length of double helix DNA. On the other hand, classical organic intercalator such as ethidium bromide increased the relative viscosity with increasing of an axial length of the DNA [41-43]. To observe covalent binding or classical organic interaction, their relative specific viscosities $\left(\eta / \eta^{0}\right)^{1 / 3}\left(\eta^{0}\right.$ and $\eta$ being specific viscosity contributions of DNA with and without complexes, resp.) were plotted against $1 / R(R=$ $[\mathrm{DNA}] /[$ complex $]=0.2,0.6,1.0,1.4,1.8)($ Figure 6$)$.

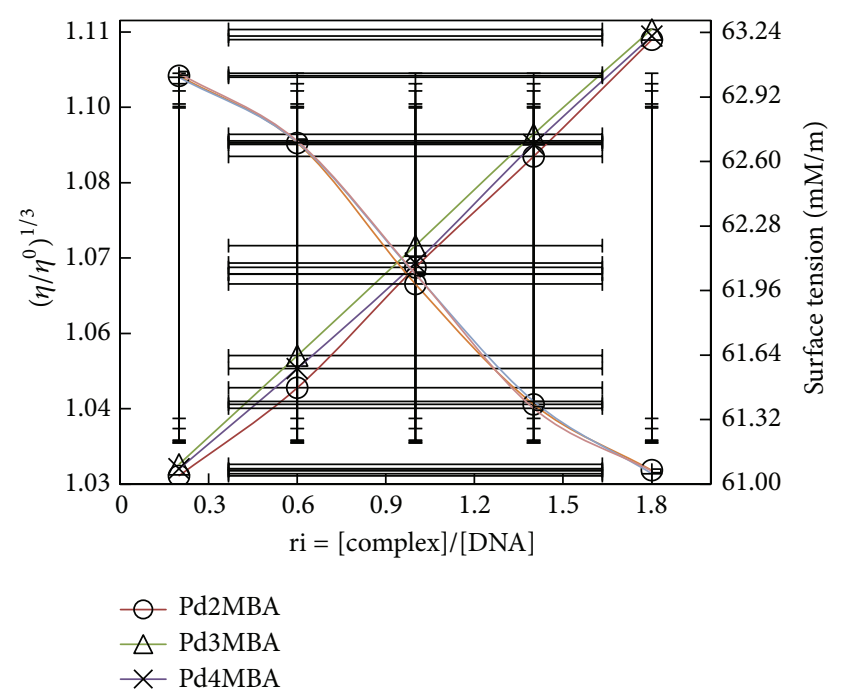

FIGURE 6: Effect of increasing amounts of Pd based benzylamine complexes on viscosity and surface tension of CT-DNA $\left(5 \times 10^{-5} \mathrm{M}\right)$.

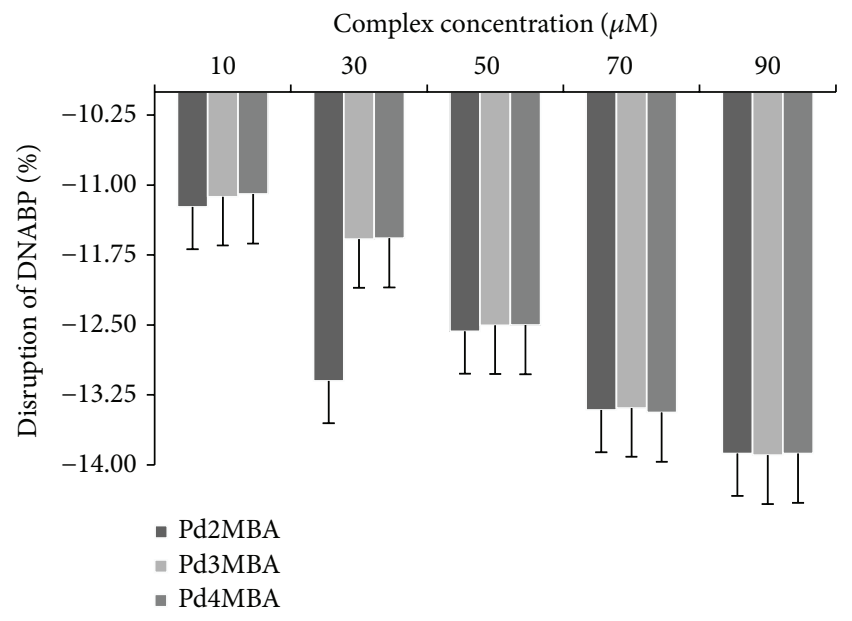

FIGURE 7: \% disruption of DNA base pairs interaction.

On increasing concentration of $\mathrm{Pd}(\mathrm{BLs})_{2}$, an increase in viscosity of DNA was observed, proving the $\mathrm{Pd}(\mathrm{BLs})_{2}$ as DNA intercalators (Figure 6). For ethidium bromide, the relative viscosity of DNA is increased with a slope from 0 to $0.9448 \mathrm{~L} / \mathrm{mM}$ [44], whereas with 0.001 the relative viscosity of DNA has increased for Pd2MBA, Pd3MBA, and Pd4MBA. The viscosity of free ligand (2-methylbenzylamine) with DNA was measured and found lower than the complexes + DNA, which inferred that interaction of DNA with free ligand is weaker as compared to complex. Therefore, a higher increase in viscosity of Pd complex + DNA as compared to free ligands clearly explained the stronger intercalation between complexes and DNA [42]. The constant value of the slope and increasing values of viscosity infer almost similar intercalating nature for all the complexes. 
Complex Contributions towards Intercalation with DNA Base Pairs. Apart from the above discussion, we have also established the $\%$ binding affinity with respect to viscosity $(\eta)$ using two different methods. In both methods the $\%$ complex on the intercalation with DNA was calculated:

\%Intercalating strength of complexes

$$
\begin{aligned}
= & \frac{\eta \text { of DNA with complexes }-\eta \text { of pure DNA }}{\eta \text { of pure DNA }} \\
& \times 100 \text {. }
\end{aligned}
$$

Figure 8 clearly explains the individual BA of complexes with DNA base pairs (DNABP). The Pd2MBA, Pd3MBA, and Pd4MBA expressed lower BA when they interacted with DNA.

(3) Conductivity and Zeta Potential. The DNA and complexes are charge molecules; therefore their conductivity and zeta potential have also been considered as interaction parameters as well as key factors for an analyzing conformational behaviour of an isolated DNA chain with the complexes. A DNA solution of $50 \mu \mathrm{M}$ had $3426 \mu \mathrm{S}$ conductivity while, with increasing amounts of complexes, the decrease in zeta potential as well as conductivities has been found (Figure 9 and Table 2). DNA molecules are negatively charged due to phosphate groups, but due to interaction with complexes their negative charge density is decreased due to Columbic interaction of positively charged complexes and the disassociation of counter ions in DNA.

The decrease in conductivity and zeta potential confirmed that the DNA could structurally be modified due to such interactions.

4.4. Drug Efficacy Studies or DFI with DNA Binding. For the better understanding of $\mathrm{Pd}(\mathrm{BLs})_{2}+\mathrm{DNA}$ interaction and their disruption during an intercalation process, DFI has found reliable data in support of anticancer activity [42]. Therefore, our study infers that the $\mathrm{Pd}(\mathrm{BLs})_{2}+\mathrm{DNA}$ interactions at different concentration have shown their higher viscosities and lower surface tension with respect to DNA solution (Figure 6). Thus, a disruption of DNABP decreases surface tension by developing an interaction between complexes and DNA.

4.5. Scavenging Activities. The scavenging activities have been investigated to support the anticancer potential of such complexes [43, 44]. Recently it is reported that, by using hydroxyl radicals, an inorganic radical (most dangerous reactive oxygen species) with its precursor such as $\mathrm{H}_{2} \mathrm{O}_{2}$ proposed the facts responsible for their mode of mechanism [43]. On the basis of the above study, the antioxidant activities have studied and analyzed the decrease in absorbance or scavenging effect of a stable free $\mathrm{DPPH}^{\bullet}$ as per standard procedure for the $\mathrm{Pd}(\mathrm{BLs})_{2}[45,46]$. The percentage scavenging activity of $\mathrm{Pd}(\mathrm{BLs})_{2}$ has been determined in a concentrationdependent mode in comparison with the $\mathrm{DPPH}^{\bullet}$ absorption at $517 \mathrm{~nm}$ [47-50]. The $\mathrm{DPPH}^{\circ}$ free radical's absorption at $517 \mathrm{~nm}$ with DMSO was 0.906 and for Pd(BLs) $)_{2}$. From 50 to
TABLE 2: Conductivity $(\mu \mathrm{S})$ of DNA and DNA + complexes.

\begin{tabular}{lcccccc}
\hline \multicolumn{7}{c}{ Conductivity/ $\mu$ S } \\
\hline & $0.00^{*}$ & 10 & 30 & 50 & 70 & 90 \\
Pd2MBA & 3426 & 3053 & 3013 & 2974 & 2903 & 2898 \\
Pd3MBA & 3426 & 2988 & 2978 & 2966 & 2952 & 2912 \\
Pd3MBA & 3426 & 2761 & 2687 & 2645 & 2581 & 2555 \\
\hline
\end{tabular}

$*$ refers to $50 \mu \mathrm{M}$ DNA.

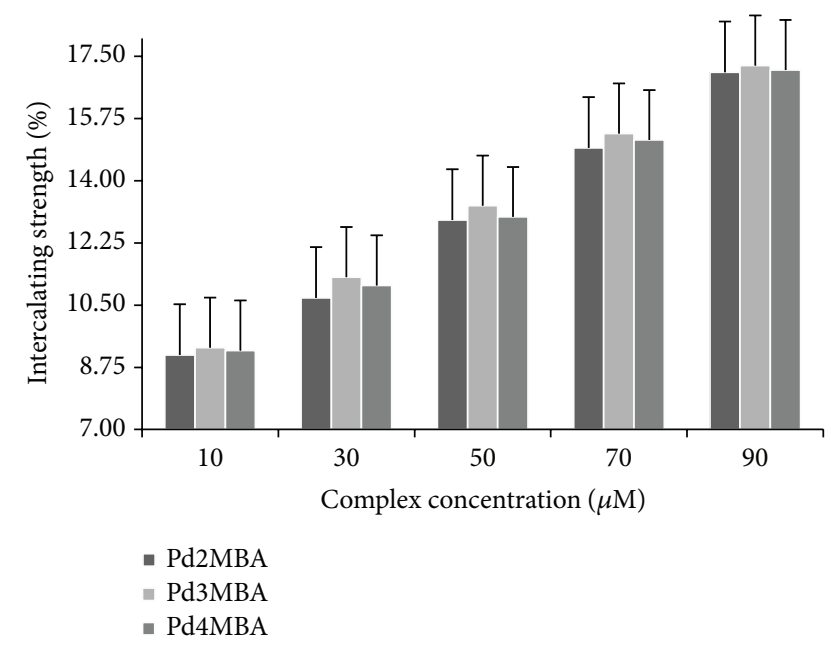

FIGURE 8: \% intercalating strength of complexes with DNA base pairs.

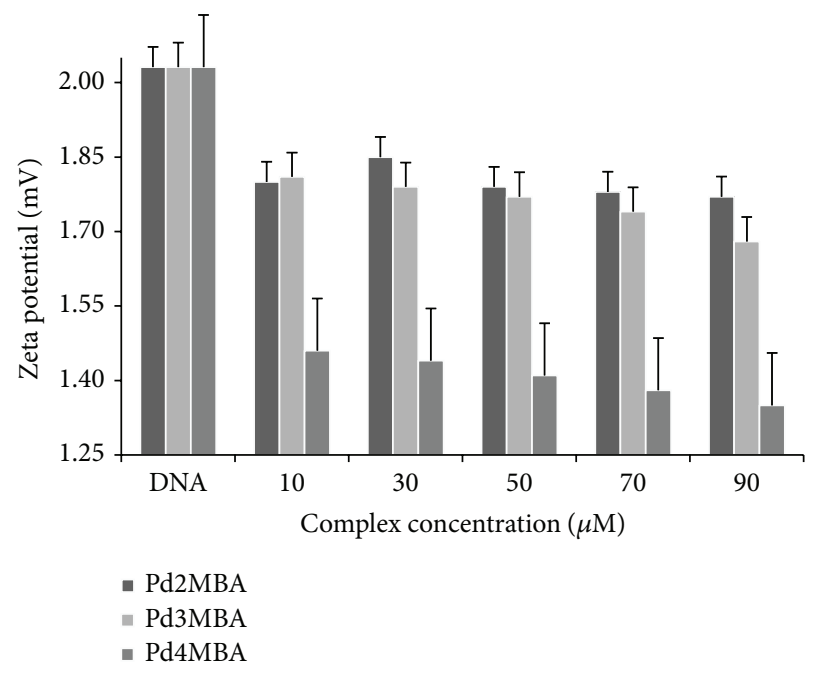

Figure 9: Zeta potential (mV) of pure DNA and DNA + complexes.

$250 \mu \mathrm{M}$ with an interval of $50 \mu \mathrm{M}$, complexes have expressed a decrease in absorption (Figure 10) that characterised them as an antioxidant [51].

The 55.47, 28.812, and 24.24\% for Pd2MBA, Pd3MBA, and $\mathrm{Pd} 4 \mathrm{MBA}$, respectively, inferred $\mathrm{Pd} 2 \mathrm{MBA}$, a strong antioxidant among them. Thus, the antioxidant activities of $\mathrm{Pd}$ complexes have inferred their significance in medicinal sciences. 


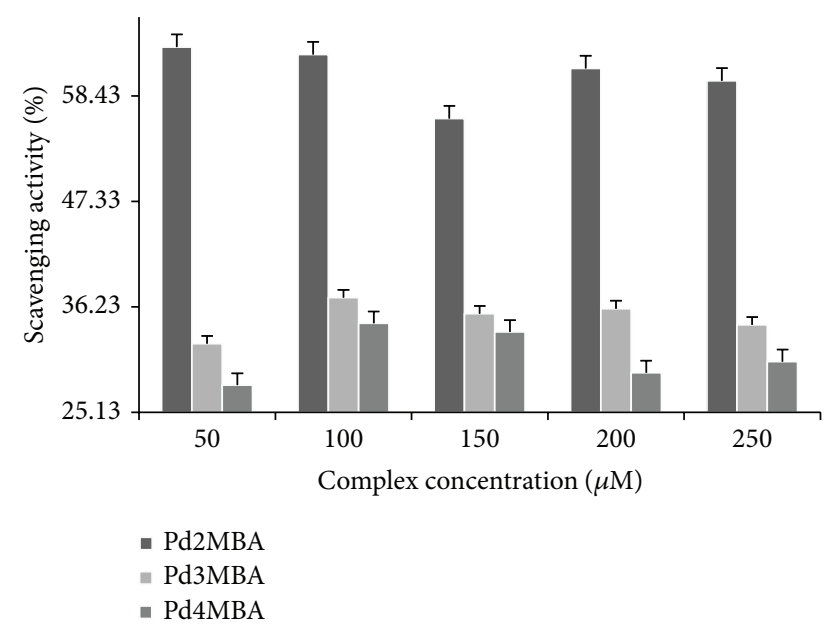

FIGURE 10: Free radical scavenging activities of synthesized complexes.

\section{Conclusion}

Since the synthesized Pd(BLs) ${ }_{2}$ could not express the anticancer activity, their DBA and SA refer them as anticancer compounds having some modification. The closer $\mathrm{GI}_{50}$ values as compared to control drugs such as doxorubicin and cisplatin make the synthesized complexes more interesting to test against other cancerous cell lines. The DBA analysis with viscosity, surface tension, zeta potential, and conductance has inferred strong intercalating as well as DNA disruption and intercalating nature of the complexes. The quantitative evaluation of \% DNABP disruption and \% intercalating strength advances the DNA binding mechanism. The complexes have shown significant free radical scavenging activities acting as antioxidants and could be used for medicinal purposes. Thereby, our study could have potential in better understanding of medicinal aspects of the complexes.

\section{Supporting Information}

It includes UV/Vis spectra of stability, DNA binding, and conductivities (DNA + complexes) of the complexes.

\section{Conflict of Interests}

The authors declare that there is no conflict of interests regarding the publication of this paper.

\section{Acknowledgment}

The authors are thankful to Central University of Gujarat, Gandhinagar, for financial, infrastructural support and experimental facilities.

\section{References}

[1] P. J. Loehrer and L. H. Einhorn, "Drugs five years later. Cisplatin," Annals of Internal Medicine, vol. 100, no. 5, pp. 704$713,1984$.
[2] C. A. Puckett and J. K. Barton, "Mechanism of cellular uptake of a ruthenium polypyridyl complex," Biochemistry, vol. 47, no. 45, pp. 11711-11716, 2008.

[3] K. L. Haas and K. J. Franz, "Application of metal coordination chemistry to explore and manipulate cell biology," Chemical Reviews, vol. 109, no. 10, pp. 4921-4960, 2009.

[4] F. Liu, W. Zhang, S. He, L. Wang, and X. Liu, "Synthesis, crystal structure and properties of the binuclear complex $\left[\mathrm{Sm}_{2}\left(\mathrm{C}_{10} \mathrm{H}_{9} \mathrm{~N}_{2} \mathrm{O}_{4}\right)_{2}\left(\mathrm{C}_{10} \mathrm{H}_{8} \mathrm{~N}_{2} \mathrm{O}_{4}\right)_{2}\left(\mathrm{H}_{2} \mathrm{O}\right)_{4}\right]$," Journal of Chemical Crystallography, vol. 38, no. 10, pp. 755-760, 2008.

[5] J. R. Benson, I. Jatoi, M. Keisch, F. J. Esteva, A. Makris, and V. C. Jordan, "Early breast cancer," The Lancet, vol. 373, no. 9673, pp. 1463-1479, 2009.

[6] M. Galanski, "Recent developments in the field of anticancer platinum complexes," Recent Patents on Anti-Cancer Drug Discovery, vol. 1, no. 2, pp. 285-295, 2006.

[7] E. Gao, C. Liu, M. Zhu, H. Lin, Q. Wu, and L. Liu, "Current development of $\mathrm{Pd}(\mathrm{II})$ complexes as potential antitumor agents," Anti-Cancer Agents in Medicinal Chemistry, vol. 9, no. 3, pp. 356-368, 2009.

[8] A. S. Abu-Surrah, K. A. Abu Safieh, I. M. Ahmad et al., "New palladium(II) complexes bearing pyrazole-based Schiff base ligands: synthesis, characterization and cytotoxicity," European Journal of Medicinal Chemistry, vol. 45, no. 2, pp. 471-475, 2010.

[9] D. S. Gill, "Structure activity relationship of antitumor palladium complexes," in Platinum Coordination Complexes in Cancer Chemotherapy, M. P. Hacker, E. B. Douple, and I. H. Krakoff, Eds., vol. 17 of Developments in Oncology, pp. 267-278, Springer, New York, NY, USA, 1984.

[10] N. A. Al-Masoudi, B. H. Abdullah, A. H. Essa, R. Loddo, and P. LaColla, "Platinum and palladium-triazole complexes as highly potential antitumor agents," Archiv der Pharmazie, vol. 343, no. 4, pp. 222-227, 2010.

[11] A. Divsalar, A. A. Saboury, H. Mansoori-Torshizi, and F. Ahmad, "Design, synthesis, and biological evaluation of a new palladium(II) complex: $\beta$-lactoglobulin and K562 as targets," Journal of Physical Chemistry B, vol. 114, no. 10, pp. 3639-3647, 2010.

[12] G. Tamasi, M. Casolaro, A. Magnani et al., "New platinumoxicam complexes as anti-cancer drugs. Synthesis, characterization, release studies from smart hydrogels, evaluation of reactivity with selected proteins and cytotoxic activity in vitro," Journal of Inorganic Biochemistry, vol. 104, no. 8, pp. 799-814, 2010.

[13] V. Mahalingam, N. Chitrapriya, F. R. Fronczek, and K. Natarajan, "Dimethyl sulfoxide ruthenium(II) complexes of thiosemicarbazones and semicarbazone: synthesis, characterization and biological studies," Polyhedron, vol. 27, no. 13, pp. 2743-2750, 2008.

[14] J. Cao, X. Xia, X. Chen, J. Xiao, and Q. Wang, “Characterization of flavonoids from Dryopteris erythrosora and evaluation of their antioxidant, anticancer and acetylcholinesterase inhibition activities," Food and Chemical Toxicology, vol. 51, no. 1, pp. 242-250, 2013.

[15] A. Huber, P. Thongphasuk, G. Erben et al., "Significantly greater antioxidant anticancer activities of 2,3-dehydrosilybin than silybin," Biochimica et Biophysica Acta (BBA)-General Subjects, vol. 1780, no. 5, pp. 837-847, 2008.

[16] S. M. M. Shanab, S. S. M. Mostafa, E. A. Shalaby, and G. I. Mahmoud, "Aqueous extracts of microalgae exhibit antioxidant and anticancer activities," Asian Pacific Journal of Tropical Biomedicine, vol. 2, no. 8, pp. 608-615, 2012. 
[17] P. Skehan, R. Storeng, D. Scudiero et al., "New colorimetric cytotoxicity assay for anticancer-drug screening," Journal of the National Cancer Institute, vol. 82, no. 13, pp. 1107-1112, 1990.

[18] P. Zhao, L.-C. Xu, J.-W. Huang et al., “Tricationic pyridium porphyrins appending different peripheral substituents: experimental and DFT studies on their interactions with DNA," Biophysical Chemistry, vol. 135, no. 1-3, pp. 102-109, 2008.

[19] P. Zhao, L.-C. Xu, J.-W. Huang et al., "Experimental and DFT studies on DNA binding and photocleavage of two cationic porphyrins: effects of the introduction of a carboxyphenyl into pyridinium porphyrin," Spectrochimica Acta Part A: Molecular and Biomolecular Spectroscopy, vol. 71, no. 4, pp. 1216-1223, 2008.

[20] P. Zhao, L.-C. Xu, J.-W. Huang et al., "DNA-binding and photocleavage properties of cationic porphyrin-anthraquinone hybrids with different lengths of links," Bioorganic Chemistry, vol. 36, no. 6, pp. 278-287, 2008.

[21] J. Z. Lu, Y. F. Du, H. W. Guo, J. Jiang, X. D. Zeng, and L. Q. Zang, "Two oxovanadium complexes incorporating thiosemicarbazones: synthesis, characterization, and DNAbinding studies," Journal of Coordination Chemistry, vol. 64, no. 7, pp. 1229-1239, 2011.

[22] Y.-F. Du, J.-Z. Lu, H.-W. Guo et al., "DNA binding and photocleavage properties of two mixed-ligand oxovanadium complexes," Transition Metal Chemistry, vol. 35, no. 7, pp. 859$864,2010$.

[23] N. Shahabadi, S. Kashanian, and M. Purfoulad, "DNA interaction studies of a platinum(II) complex, $\mathrm{PtCl}_{2}(\mathrm{NN})(\mathrm{NN}=4,7-$ dimethyl-1,10-phenanthroline), using different instrumental methods," Spectrochimica Acta Part A: Molecular and Biomolecular Spectroscopy, vol. 72, no. 4, pp. 757-761, 2009.

[24] M. Singh, "Survismeter-type I and II for surface tension, viscosity measurements of liquids for academic, and research and development studies," Journal of Biochemical and Biophysical Methods, vol. 67, no. 2-3, pp. 151-161, 2006.

[25] M. Singh, "Survismeter, 2-in-1 for viscosity and surface tension measurement, an excellent invention for industrial proliferation of surface forces in liquids," Surface Review and Letters, vol. 14, no. 5, pp. 973-983, 2007.

[26] Y. Sun, S. Gou, R. Yin, and P. Jiang, "Synthesis, antiproliferative activity and DNA binding study of mixed ammine/cyclohexylamine platinum(II) complexes with 1(substituted benzyl) azetidine-3, 3-dicarboxylates," European Journal of Medicinal Chemistry, vol. 46, no. 10, pp. 5146-5153, 2011.

[27] A. D. Allen and C. V. Senoff, "Preparation and infrared spectra of some ammine complexes of ruthenium(II) and ruthenium(III)," Canadian Journal of Chemistry, vol. 45, no. 12, pp. 1337-1341, 1967.

[28] N. D. Ball, J. W. Kampf, and M. S. Sanford, "Synthesis and reactivity of palladium(II) fluoride complexes containing nitrogendonor ligands," Dalton Transactions, vol. 39, no. 2, pp. 632-640, 2010.

[29] L. Trynda, D. Kwiatkowska, and W. Tyran, "Platinum complexes and pyruvate kinase activity," General Physiology and Biophysics, vol. 17, no. 1, pp. 25-36, 1998.

[30] C. Gao, F. Fei, T. Wang et al., "Synthesis and in vitro cytotoxicity of platinum(II) complexes with chiral N-monosubstituted 1,2cyclohexyldiamine derivatives as the carrier groups," Journal of Coordination Chemistry, vol. 66, no. 6, pp. 1068-1076, 2013.
[31] L. Li, J. Zhang, L. Ma et al., "Synthesis, characterization, and cytotoxicity of platinum(II)/palladium(II) complexes with 4toluenesulfonyl-L-amino acid dianion and diimine/diamine," Journal of Coordination Chemistry, vol. 66, no. 4, pp. 638-649, 2013.

[32] M. N. Patel, P. A. Dosi, and B. S. Bhatt, "Square planar palladium(II) complexes of bipyridines: synthesis, characterization, and biological studies," Journal of Coordination Chemistry, vol. 65, no. 21, pp. 3833-3844, 2012.

[33] J. Zhang, F. Zhang, L. Wang, J. Du, S. Wang, and S. Li, "Synthesis, characterization, and cytotoxicity of complexes of platinum(II) with 2,2'-bipyridine and $N$-benzoyl- $L$-amino acid dianion," Journal of Coordination Chemistry, vol. 65, no. 12, pp. 2159-2169, 2012.

[34] M. Navarro, W. Castro, A. R. Higuera-Padilla et al., "Synthesis, characterization and biological activity of trans-platinum(II) complexes with chloroquine," Journal of Inorganic Biochemistry, vol. 105, no. 12, pp. 1684-1691, 2011.

[35] B.-D. Wang, Z.-Y. Yang, P. Crewdson, and D.-Q. Wang, "Synthesis, crystal structure and DNA-binding studies of the $\operatorname{Ln}(\mathrm{III})$ complex with 6-hydroxychromone-3-carbaldehyde benzoyl hydrazone," Journal of Inorganic Biochemistry, vol. 101, no. 10, pp. 1492-1504, 2007.

[36] J. K. Barton, J. J. Dennenberg, and J. B. Chaires, "Tris(phenanthroline)ruthenium(II) enantiomer interactions with DNA: mode and specificity of binding," Biochemistry, vol. 32, no. 10, pp. 2573-2584, 1993.

[37] R. F. Pasternack, E. J. Gibbs, and J. J. Villafranca, "Interactions of porphyrins with nucleic acids," Biochemistry, vol. 22, no. 10, pp. 2406-2414, 1983.

[38] G. Pratviel, J. Bernadou, and B. Meunier, "DNA and RNA cleavage by metal complexes," Advances in Inorganic Chemistry, vol. 45, pp. 251-312, 1998.

[39] J. Lu, H. Guo, X. Zeng et al., "Synthesis and characterization of unsymmetrical oxidovanadium complexes: DNA-binding, cleavage studies and antitumor activities," Journal of Inorganic Biochemistry, vol. 112, pp. 39-48, 2012.

[40] R. K. Ameta and M. Singh, "SAR and DFI studies of supramolecular tetraammoniumplatinate + DNA matrix with UV/Vis spectrophotometry and physicochemical analysis at 298.15 K," Journal of Molecular Liquids, vol. 190, pp. 200-207, 2014.

[41] L. Kapicak and E. J. Gabbay, “Topography of nucleic acid helixes in solutions. XXXIII. Effect of aromatic cations on the tertiary structures of deoxyribonucleic acid," Journal of the American Chemical Society, vol. 97, pp. 403-408, 1975.

[42] E. C. Long and J. K. Barton, "On demonstrating DNA intercalation," Accounts of Chemical Research, vol. 23, no. 9, pp. 271-273, 1990.

[43] D. Meyerstein, "Comment on the section: 'antioxidant measurements and hydroxyl radical scavenging activity' in synthesis, characterization, DNA binding, and antioxidant activities of four copper(II) complexes containing N-(3-hydroxybenzyl)amino amide ligands," Journal of Coordination Chemistry, vol. 66, pp. 2076-2078, 2013.

[44] K. Jomova, S. Baros, and M. Valko, "Redox active metalinduced oxidative stress in biological systems," Transition Metal Chemistry, vol. 37, no. 2, pp. 127-134, 2012.

[45] Z. A. Taha, A. M. Ajlouni, W. Al Momani, and A. A. Al-Ghzawi, "Syntheses, characterization, biological activities and photophysical properties of lanthanides complexes with a tetradentate 
Schiff base ligand," Spectrochimica Acta Part A: Molecular and Biomolecular Spectroscopy, vol. 81, no. 1, pp. 570-577, 2011.

[46] R. Trivedi, S. B. Deepthi, L. Giribabu et al., "Synthesis, crystal structure, electronic spectroscopy, electrochemistry and biological studies of Ferrocene-Carbohydrate conjugates," European Journal of Inorganic Chemistry, no. 13, pp. 2267-2277, 2012.

[47] D. Suh and J. B. Chaires, "Criteria for the mode of binding of DNA binding agents," Bioorganic and Medicinal Chemistry, vol. 3, no. 6, pp. 723-728, 1995.

[48] F.-H. Li, G.-H. Zhao, H.-X. Wu et al., "Synthesis, characterization and biological activity of lanthanum(III) complexes containing 2-methylene-1,10-phenanthroline units bridged by aliphatic diamines," Journal of Inorganic Biochemistry, vol. 100, no. 1, pp. 36-43, 2006.

[49] M. E. Howe-Grant and S. J. Lippard, "Aqueous platinum (II) chemistry; binding to biological molecules," Metal Ions in Biological Systems, vol. 20, pp. 63-125, 1980.

[50] R. K. Ameta, M. Singh, and R. K. Kale, "Synthesis and structureactivity relationship of benzylamine supported platinum(IV) complexes," New Journal of Chemistry, vol. 37, no. 5, pp. 15011508, 2013.

[51] A. M. J. Fichtinger-Schepman, J. L. Van der Veer, J. H. J. Den Hartog, P. H. M. Lohman, and J. Reedijk, "Adducts of the antitumor drug cis-diamminedichloroplatinum(II) with DNA: formation, identification, and quantitation," Biochemistry, vol. 24, no. 3, pp. 707-713, 1985. 

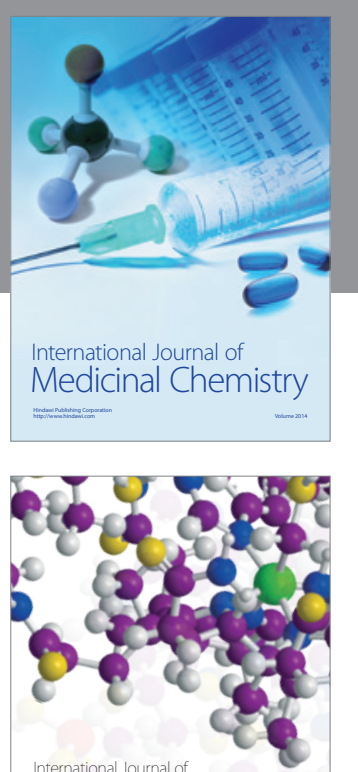

Carbohydrate Chemistry

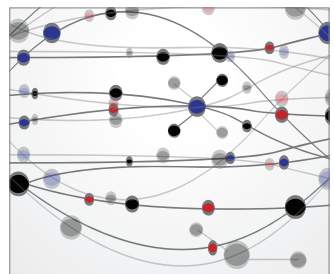

The Scientific World Journal
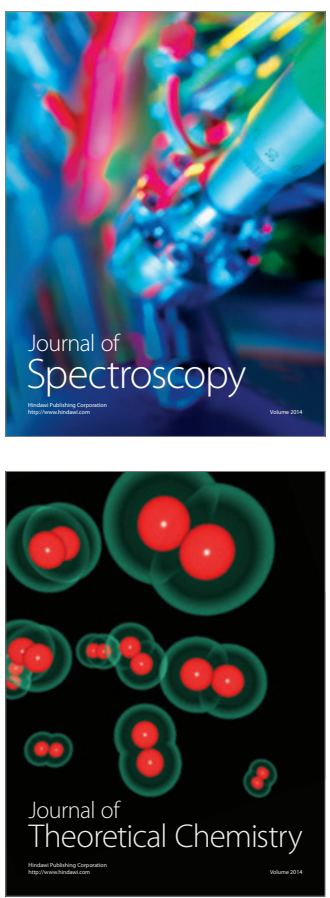
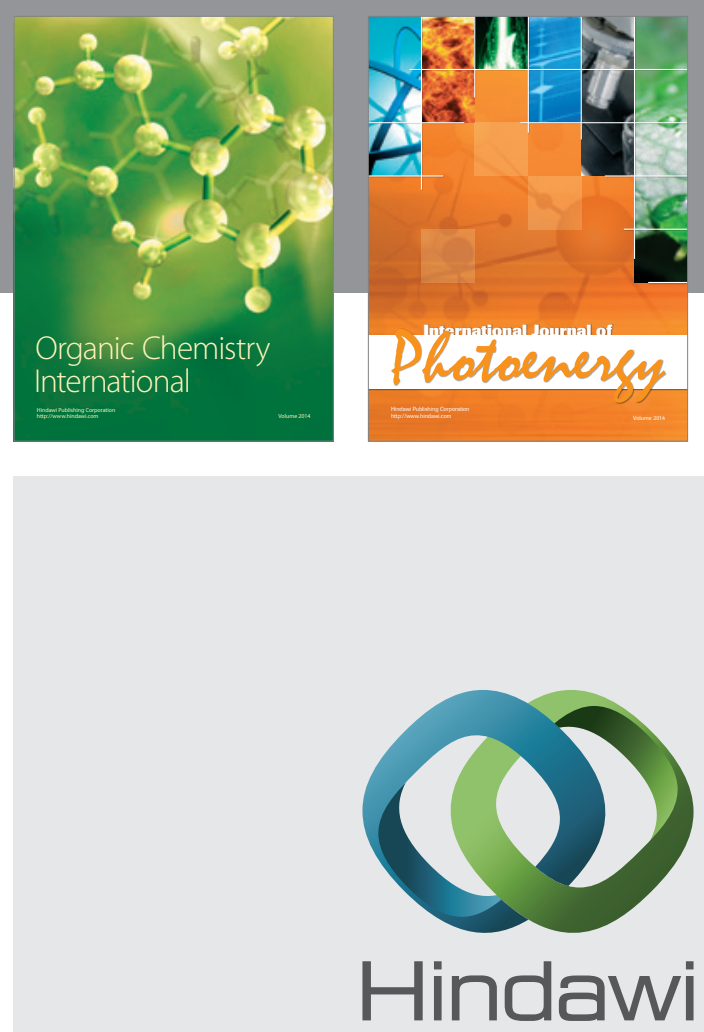

Submit your manuscripts at

http://www.hindawi.com

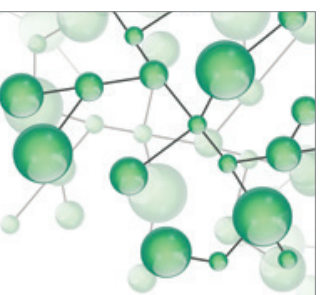

International Journal of

Inorganic Chemistry

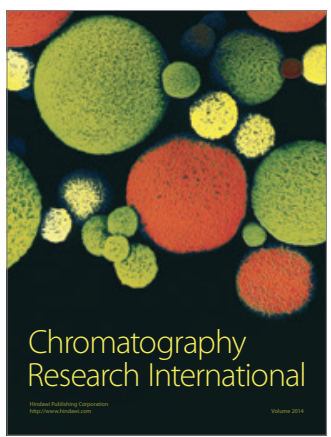

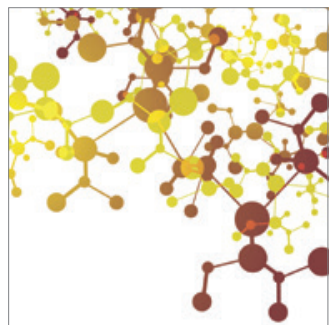

Applied Chemistry
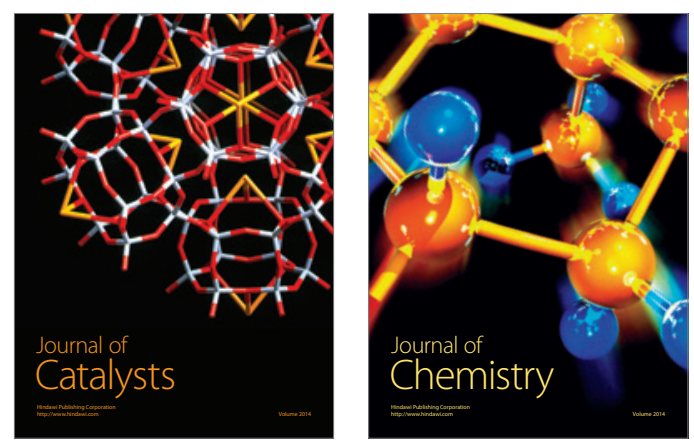
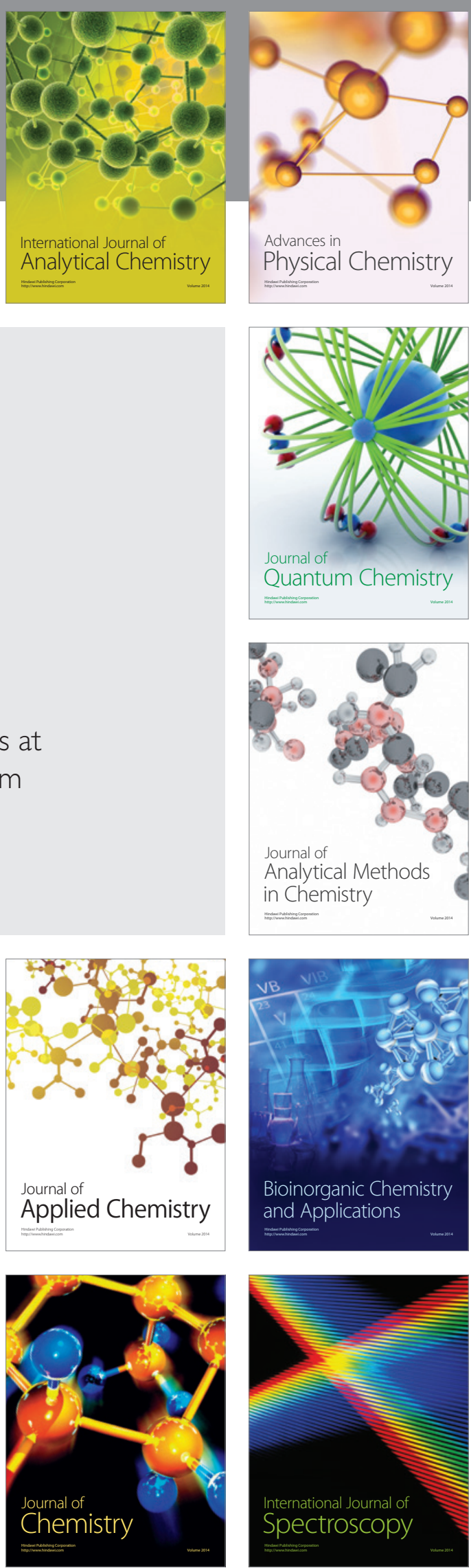